\title{
One man and his dog: Umberto $D$
}

\author{
Elaine Loughlin ${ }^{1} \cdot$ Shaun T. O'Keeffe ${ }^{1,2}$ (1)
}

Received: 29 April 2019 / Accepted: 27 May 2019 / Published online: 27 June 2019

(c) European Geriatric Medicine Society 2019

Poverty is bad for the health of older people, as for others. It may be particularly bad for mental health and, while obviously not the only factor, changes in poverty rates have been strongly associated with the rising suicide rates in the United States (and falling global rates worldwide) in recent years [1, 2]. Loss of dignity is among the most harmful characteristics of poverty. Owning a pet may be good for the mental health of, and protective against loneliness in, older people [3]. These are among the many issues beautifully dramatized in Vittorio De Sica's 1952 film Umberto D.

The story is simple. Umberto Domenico Ferrari is a retired civil servant living on a meagre pension in a shabby, rented room in Rome. He desperately needs money to avoid eviction by his unpleasant landlady. In the meantime, she rents his room out during the day to amorous couples. His only friend is Maria, the young maid in the house, who is also in trouble: she is secretly pregnant and can persuade neither of the putative fathers to support her. Umberto's main source of joy is his dog Flike-"a mutt with intelligent eyes"-and much of the film revolves around their relationship. With others he can be formal and irascible, but with Flike Umberto is a different man, happy to play with a ball and stick on the floor.

The film follows Umberto as he tries to raise money. Not really ill, he inveigles his way into hospital for a few days to be fed for free. His few valuables prove almost worthless. When he approaches his former colleagues (although, characteristically, he cannot bring himself to ask directly for money), their superficial bonhomie cannot disguise a lack of interest in his troubles. In one of the most touching scenes, he holds out his hand palm-up to beg. However, when a passer-by seems about to give him something, he hastily turns his hand over to appear as if checking for rain.

Shaun T. O'Keeffe

sokanc@iolfree.ie

1 Department of Geriatric Medicine, Galway University Hospitals, Galway, Ireland

2 Unit 4, Merlin Park University Hospital, Galway, Ireland
As his options dwindle and his humiliations mount, Umberto tells Maria that he is tired of everything and arrives at the idea of suicide. However, Flike has to be taken care of first. Umberto does not trust the couple willing to take the dog, at a price, to provide good care. He tries to get a little girl who plays with Flike in the park to take him, but her parents will not allow it. The dog finds him when he runs away and hides in the bushes. Finally, Umberto decides they should die together and takes Flike in his arms to stand in the path of an incoming train. However, Flike is frightened and wriggles away, and Umberto follows him. The film ends with Umberto playing with Flike on the grass as he tries to comfort the dog and regain its trust.

Umberto D is one of the classics of post-war Italian neorealism. Like other such films, it was shot on location, mainly featured non-actors and aimed to reflect the reality of life for ordinary people. De Sica avoids sentimentality (always a risk in a film with a cute dog), and much of the power of the movie comes from how understated it is. In one scene, the camera just follows the maid as she does her work in the kitchen. After a few minutes, she stops, pats her pregnant belly and tears roll down her face. The final scenes may be contrived, but this is no happy ending, more a moment of reprieve, for Umberto.

Umberto is a complex character. Although viewers come to care for him, he is not looking for sympathy. He is selfreliant and pernickety. (When police break up a protest march by older people seeking a raise in their pensions, his response is to blame the organizers: "They didn't even get a permit"). He is socially isolated, but it seems primarily by choice. He is kind to and concerned about Maria. It is the threat to his dignity and self-respect, and the repeated humiliations he is subject to, that, more than just lack of money, cause him to consider suicide.

Although Umberto D was critically lauded abroad, it was a flop in Italy and was attacked by politicians from all sides. Giulio Andreotti (later many-times Prime Minister of Italy) accused De Sica of "washing Italy's dirty linen in public". Others criticized him for focussing on human failings rather than economic conditions as the source of Umberto's 
troubles [4]. There is some truth in this argument, but De Sica was not making a 'message' film calling for higher pensions for older people. He dedicated the film to his father, also Umberto, whom he later described as "an old bourgeois who fought against poverty and to maintain his dignity" [5]. The film reflects this and honours his father.

Umberto D was played by Carlo Battisti, then 70, a former professor of linguistics in Florence. It is a superb performance from Battisti who had never acted before and who conveys a mixture of dignity and weariness with wonderfully expressive eyes. (The dog-somewhat of a canine ham-was one of the few professionals in the cast). Battisti did have plenty of life experience to draw on: he had been wounded in World War 1, captured by the Russians and sent to Siberia, during which time his only child died; and he was deported to Germany towards the end of World War 2.

Battisti's life after making the film carries a final gerontological message. The common and superficial description of him by film critics as 'retired' seems unjust. Instead, he went on to write, as a linguist, about the language of film and to direct a documentary about Ladin culture. He continued to work, and to publish prolifically, on the dialects of his native South Tyrol right up to his death, after a sudden illness, aged 95 in 1977. One might hope that Umberto D had as fulfilling a destiny.

\section{Compliance with ethical standards}

Conflict of interest The authors have no conflicts of interest to report.
Ethical approval This article does not contain any studies with human participants or animals performed by any of the authors.

Informed consent For this type of study, formal consent is not required.

\section{References}

1. Bailey RK, Patel TC, Avenido J, Patel M, Jaleel M, Barker NC, Khan JA, All S, Jabeen S (2011) Suicide: current trends. J Nat Med Assoc 103(7):614-617

2. Pikhartova J, Bowling A, Victor C (2014) Does owning a pet protect older people against loneliness? BMC Geriatr. https://doi. org/10.1186/1471-2318-14-106

3. Brunette P. When neo-realism collided with reality. New York Times, Feb 17, 2002. https://www.nytimes.com/2002/02/17/movie s/film-when-neo-realism-collided-with-reality.html. Accessed 8 April 2019

4. Armes Roy (1971) Patterns of realism. A. S. Barnes, South Brunswick

5. Carlo Battisti. Enciclopedia Italiana, Istituto dell'Enciclopedia Italiana. http://www.treccani.it/enciclopedia/carlo-battisti_(Encic lopedia-Italiana)/. Accessed 8 April 2019

Publisher's Note Springer Nature remains neutral with regard to jurisdictional claims in published maps and institutional affiliations. 